\title{
MILK PRODUCTION PERFORMANCE AND SOME BIOCHEMICAL BLOOD COMPONENTS IN EGYPTIAN BUFFALOES AS AFFECTED BY SEASONAL VARIATION
}

\author{
M. H. Farouk
}

Animal Production Department, Faculty of Agriculture, Al-Azhar University, Nasr City, Cairo

\section{SUMMARY}

Eighteen lactating buffaloes were used to study the effect of season on milk production performance and some blood biochemical indicators. The study included two seasons, summer and winter. Milk samples were collected at weekly intervals, while blood samples were collected after one month from calving from each animal. Plasma alanine aminotransferase (ALT), aspartate aminotransferase (AST) and alkaline phosphatase (ALP), total protein (TP), albumin, total cholesterol (TC) and triglycerides (TG) levels were determined. Results indicated that, during summer season THI values were higher than those of the thermoneutral zone, while in winter it was within the thermoneutral zone of lactating buffaloes. Milk production was significantly lower under heat stress in summer than that in winter when ambient temperature (Ta) was around the thermoneutral zone. Daily milk yield average (DMY), fat corrected milk yield (FCM) and total milk yield (TMY) in addition to milk protein \% were significantly higher in winter than those in summer season. Whereas, milk lactose, fat and total solids (TS) \% did not differ between winters and summer seasons. ALT was significantly higher in winter than in summer season, while AST, ALP, total protein (TP), albumin and globulin showed no significant differences. Albumin/globulin ratio (A/G ratio) was within normal values and did not also differ between seasons. A significant positive correlation was found between plasma ALT and each of DMY, FCM and TMY. Also, between plasma ALP levels and each of lactose, TS and SNF and plasma TG levels with milk fat \%.

In concultion, in winter season, buffaloes produced more milk and milk components than summer season. Plasma ALT activity could be used to predict TMY, FCM and average of DMY, meanwhile plasma ALP activity could be used to predict milk TS and SNF contents.

\section{Keywords: Buffalo, season, milk yield and components, blood plasma component}

\section{INTRODUCTION}

It is well known that, the main dairy animals in Egypt are water buffaloes and their milk is more preferable by consumers than cow's milk. Also, buffaloes are sensitive to weather changes and adverse climatic conditions, which are hazardous to buffalo's milk productivity (Marai and Habeeb, 2010). Many metabolites were estimated in animal's blood to give an indication of the physiological condition of the body (Sakowski et al., 2012). Blood content profiles have been used to identify dietary defect even before productivity is impaired. Such profiles have also been used to monitor herd health, to diagnose subclinical disease, to predict risk of ketosis or abomasum displacement, as well as to investigate herd problems with metabolic disorders (Geishauser, et al., 1997; Oetzel, 2004; LeBlanc et al., 2005 and Macrae et al., 2006). Production of milk requires close coordination between biochemical pathways, to supply synthesis intermediates and pathways for secretion (Akers, 2005).

Many authors declared that calving season affects on milk yield conversely Khan (1996) came to conclusion that there was no significant effect of calving season on milk yield in buffaloes.

Contradictory results had been found for the correlation between daily milk yield (DMY) and plasma alanine aminotransferase (ALT) activity where Sakowski et al. (2012) found a significant negative correlation between DMY and plasma ALT activity, while Jozwik et al. (2012) found a significant positive correlation between the same variables.

The objectives of the present study were to evaluate the effect of seasonal changes on buffalo milk production and characteristics and find out the relation between these characteristics to some plasma parameters.

\section{MATERIALS AND METHODS}

Eighteen buffalo cows representing four parities were kept in open yard $\left(30 \times 70 \mathrm{~m}^{2}\right)$ at Mostorod Research Farm belonging to the Animal Production Department, Faculty of Agriculture, Al-Azhar University. All animals were tested after about one month of parturition. Half of the buffaloes $(n=9)$ 
delivered in 2008 during summer season while the rest buffaloes delivered in 2009 during winter season. Buffaloes were tested to evaluate the differences between milk characteristics in the winter and summer months of Egypt. The overall mean minimum and maximum ambient temperatures are presented in table (1). Animals were fed concentrate fed mixture and green fodder, berseem (Trifolium alexandrinum) in winter and corn fodder (Zea maiz), (Darawa) in summer according to Ghoneim (1967). Milk yield of each buffalo was weighed and samples of $20 \mathrm{ml}$ were collected twice daily in the morning and evening by hand milking at weekly interval. Samples were mixed and preserved in plastic sterilized vials with two drops of potassium dichromate till assayed. Blood samples were also collected from the jugular vein in heparinized vials. Plasma samples were immediately centrifugated and plasma samples were obtained and stored at $-20^{\circ} \mathrm{C}$ until determination of alanine aminotransferase (ALT), aspartate aminotransferase (AST) and alkaline phosphatase (ALP), total protein (TP), albumin, total cholesterol (TC) and triglycerides (TG) using a commercial kit (Biodiagnostic, Egypt).

Milk components (fat, protein, lactose, total solids, and solids not fat) were determined by Milko Scan 130 tester type: 10900 based on infrared spectroscopy (AOAC, 1990). The 7\% fat corrected milk yield (FCM) values were calculated by the formula: FCM $(\mathrm{kg})=0.28 \times$ MY $(\mathrm{kg})+10.34 \times$ milk fat $(\mathrm{kg})$, according to Tyrrell and Reid (1965).

Meteorological data were obtained from Central Laboratory of Agricultural Climate. Temperature humidity index (THI) was calculated using the formula of Amundson et al. (2006) as follows:

$\mathrm{THI}=0.8 \times \mathrm{Ta}{ }^{\circ} \mathrm{C}+\left\{(\mathrm{RH} \%) \times\left(\mathrm{Ta}^{\circ} \mathrm{C}-14.4\right)\right.$ / 100) $\}+46.4$.

Where; $\mathrm{Ta}{ }^{\circ} \mathrm{C}$ is the ambient temperature $\left({ }^{\circ} \mathrm{C}\right)$, and $\mathrm{RH}$ is the relative humidity (RH \%) / 100.

Statistical analysis was carried out using SPSS Program (SPSS, 1999). Averages during summer and winter seasons were used for performing the $\mathrm{T}$ Test in order to find out the effect of season. Person coefficient test was used to find out the correlations between milk characteristics and plasma biochemical parameters.

\section{RESULTS AND DISCUSSION}

\section{Seasonal conditions:}

THI was higher than 78 in summer and less than 70 in winter (Table 1). THI value of 68 is considered the upper limit of dairy cattle comfort zone (Johnson et al., 1989 and Marai and Habeeb, 2010). Temperature humidity index value of 74 to 78 is considered hazardous and represents an alert condition for animals (Abd El-Ghany et al., 2010). Accordingly, animals were under severe heat stress during summer and thermoneutral zone during winter.

\section{Daily milk yield (DMY):}

Highly $(\mathrm{P} \leq 0.01)$ difference between the averages of DMY in winter and summer seasons was found (Table 2). Increased DMY in winter occurred when ambient temperature was almost around the thermoneutral zone. In summer THI was extremely high $(>78)$ which depressed DMY. It is well established that high ambient temperature during summer reduces the animal appetite and feed intake, and impairs milk production (Marai and Habeeb, 2010). In this connection, Kamiya et al. (2005), Hussain et al. (2006) Tanaka et al. (2007), Javed et al. (2009) and Marai and Habeeb (2010) reported that milk production changes in both dairy cows and buffaloes due to the change in specific biological functions such as increasing body temperature and enzymatic reactions by climate changing.

\section{Total milk yield and 7\% fat corrected milk yield:}

The average TMY showed higher $(\mathrm{P} \leq 0.01)$ values in winter than in summer season (Table 2). The corresponding averages of $7 \%$ FCM yield showed highly significant differences $(\mathrm{P} \leq 0.01)$ between winter and summer while milk fat $\%$ was almost similar (Table 2). These remarkable differences may be due to higher milk yield in winter as compared to summer.

\section{Milk composition:}

Milk protein $(\%)$ was higher $(\mathrm{P} \leq 0.05)$ in winter than in summer, while milk lactose (\%), fat $(\%)$ and TS did not differ between the two studied seasons. Thus, $\operatorname{SNF}(\%)$ was higher $(\mathrm{P} \leq 0.05)$ in winter than in summer season. The seasonal variation in milk components which might be found in some European countries was not clear in most of the milk components of buffaloes under the Egyptian conditions. This could be attributed to differences in ambient temperature and light/darkness ratio beside differences in feed quality and feed intake (Table 1).

Seasonal effects was observed in milk protein and in milk fat contents. This might ascribe that the expansion of light-to-dark ratio leading to a reduction in fat and protein contents of milk, probably as a consequence of a greater secretion of prolactin which is reported to be higher in summer than in winter 
(Sevi et al., 2004). Hence Ozrenk and Inci (2008) found that milk fat, protein and total solids percentages were the highest during the winter and the lowest during the summer season.

\section{Blood parameters:}

Alanine aminotransferase (ALT) was higher $(\mathrm{P} \leq 0.05)$ in winter than in summer, while AST and ALP showed non significant differences between the two seasons (Table 3). Koubkova et al. (2002) and Rasooli et al. (2004) found that the increase in ambient temperature enhanced ALT activities in cattle. On the other hand, Abo El-Nor et al. (2007) and Sobiech et al. (2008) reported that ALT, activity may increase with the high metabolism which accompany to high milk production in winter seasons.

\section{Plasma proteins:}

Plasma total protein as well as albumin and globulin concentrations showed nonsignificant differences in the two studied seasons. Moreover, A/G ratio was within the normal range and did not differ significantly between seasons (Table 3). These results are in agreement with those previously reported by Kumar and Puri (2009) who stated that no significant differences between summer and winter were detected in serum protein levels in buffaloes. On the other, hand Gudev et al. (2007) found significant differences between plasma proteins in both summer and winter seasons. They demonstrated that heat exposure causes initial hemoconcentration followed by hemodilution in buffaloes. This variability may cause high fluctuations in plasma protein values in this study.

\section{Lipid profile:}

Plasma TC in summer season was significantly lower than in winter (Table 3). Triglycerides (TG) did not show significant differences between seasons. The significantly higher plasma TC concentration in winter than in summer may be due to the increase in thyroxin secretion in winter. Rasooli et al. (2004) demonstrated that cold environment stimulated thyroid hormone secretion to increase basal metabolic rate in order to maintain body temperature, which accompanies high levels of blood metabolites such as cholesterol.

These results are in agreement with those reported by Verma et al. (2000) who found lower levels of serum TC during summer than during winter season, in lactating Murrah buffaloes. In this hence, Shafferi et al. (1981), Abdel-Samee (1987) Marai et al. (1995), and Habeeb et al. (1996) reported that cholesterol concentration in plasma TC decreases with the increase in ambient temperature. The decrease in TC levels may be due to dilution as a result of the increase in total body water or to the decrease in acetate concentration, which is the initial precursor for the synthesis of cholesterol. The marked increase in glucocorticoid hormone level may be another factor causing the decline in blood cholesterol during heat stress (Marai and Habeeb, 2010).

\section{Correlations between milk and blood parameters:}

Plasma ALT showed significant positive correlation with each of DMY, FCM and TMY (Table 4), while plasma AST activities were not significantly correlated with any milk characteristics. These results agree with the results of Jozwik et al. (2012) who found positive correlation between DMY and plasma ALT activities. This is not in harmony with Sakowski et al. (2012) who found negative correlation between ALT and TMY. The significant positive correlation between ALT and milk characteristics indicates that milk production is in direct relation with the activity of transaminase enzymes, which is related to metabolism and lactation process (Abo El-Nor et al., 2007 and Sobiech et al., 2008).

Lactose levels were significantly and positively correlated with plasma ALP, which may be due to dephosphorylation process connected with carbohydrate metabolism or even with the capture of blood sugar molecules by the mammary gland cells (Folley and Greenbaum, 1947; and Kuhn and Lowenstein; 1967). Akers (2005) stated that lactose production, may require $85 \%$ of the available glucose. Also, ALP is a mediator enzyme in lactose synthesis via activation of lactose synthetase enzyme (Leung et al., 1989), which serves to combine glucose and galactose and thereby form lactose. Hence, TS, SNF and lactose were positively and significantly correlated with ALP (Table 4).

Plasma TG were positively correlated to milk fat \% (Table, 4). This relation could be explained by the previous finding that fat levels are influenced by plasma lipid concentrations (Mc Namara et al., 1995 and Tekelioglu et al., 2010). In addition, Likewise Hammon et al. (2009) reported that high intensive fat metabolism occurs to provide milk fat. Furthermore, the positive correlation between plasma TG and milk fat \% may be attributed to that milk fat is composed primarily of fatty acids esterified as triacyl glycerols (97 to $99 \%$ by weight) and are packaged in fat globules enveloped in cell membrane (Oftedal, 2005). 
TC was significantly and positively correlated with FCM. These results may be ascribed to the fat secreted droplets, which have cholesterol engulfed by plasma membrane and secreted from the cell to the lumen (Akers, 2005).

\section{CONCLUSION}

Based on the obtained results, season showed a significant effect on milk production and components where in winter season, buffaloes produced higher milk and milk components than those in summer season. Positive and significant correlations were observed between plasma ALT with each of TMY, DMY and FCM. Also, plasma ALP showed highly significant positive correlation with lactose \%, TS and SNF in milk. In addition, plasma TG was positively correlated with milk fat $\%$. Consequently, plasma ALT activity could be used to predict total milk yield, fat corrected milk yield and average daily milk yield, meanwhile plasma ALP activity could be used to predict milk total solids and solids not fat contents.

\section{REFERENCES}

Abd El-Ghany, W.H., A.A. El-Sherbiny, M.H. Khalil and W.A. Ramadan, 2010. Role of the wool coat density on some adaptive measurements of Barki sheep under semiarid conditions. Egypt. Basic Appl. Physiol., 9 (2): 247-263.

Abdel-Samee, A.M.,1987. The role of cortisol in improving productivity of heat-stressed farm animals with different techniques. Ph.D. Thesis, Faculty of Agriculture, Zagazig University, Zagazig, Egypt.

Abo El-Nor, S.A.H., M.H. Khattab, H.A. AlAlamy, F.A. Salem and M.M. Abdou, 2007. Effects of some medicinal plants seeds in the rations on the productive performance of lactating buffaloes. Int. J. Dairy Sci., 2 (4): 348-355.

Akers, R.M., 2005. Milk synthesis. In: W.G. Pond and A.W. Bell (eds), Encyclopedia of Animal Science. Marcel Dekker, Inc., New York, USA. pp. 629-516.

Amundson, J.L., T.L. Mader, R.J. Rasby and Q.S. Hu, 2006. Environmental effects on pregnancy rate in beef cattle. J. Anim. Sci., 84: 3415-3420.

AOAC 1990. Official Methods of Analysis. $15^{\text {th }}$ ed. Association of Official Analytical Chemists. Washington, DC.

Folley, S.J. and A.L. Greenbaum, 1947. Changes in the arginase and alkaline phosphatase contents of the mammary gland and liver of the rat during pregnancy, lactation and mammary involution. Biochem. J., 41: 261-269.

Geishauser, T., K.E. Leslie, T.F. Duffield and V. Edge, 1997. Evaluation of aspartate transaminase activity and betahydroxybutyrate concentration in blood as tests for prediction of left displaced abomasum in dairy cows. Am. J. Vet. Res., 58: $1216-1220$.

Ghoneim, A., 1967. Animal Nutrition (Feeding Requirements and Economic Rations), Anglo Press lib. (In Arabic), Cairo, Egypt.

Gudev, D., S. Popova-Ralcheva, P. Moneva, Y. Aleksiev, T. Peeva, Y. Ilieva and P. Penchev, 2007. Effect of heat-stress on some physiological and biochemical parameters in buffaloes. Ital. J. Anim. Sci., 6 (2): 1325-1328.

Habeeb, A.A.M., K.M. EL-Masry, A.I. Aboulnaga and T.H. Kamal, 1996. The effect of hot summer climate and level of milk yield on blood biochemistry and circulating thyroid and progesterone hormones in Friesian cows. Arab. J. Nuclear Sci. Applic., 29: 161-173.

Hammon, H.M., G. Stürmer, F. Schneider, A. Tuchscherer, H. Blum, T. Engelhard, A. Genzel, R. Staufenbiel and W. Kanitz, 2009. Performance and metabolic and endocrine changes with emphasis on glucose metabolism in high-yielding dairy cows with high and low fat content in liver after calving. J. Dairy Sci., 92: 1554-1566.

Hussain, Z., K. Javed, S.M.I. Hussain and G.S. Kiyani, 2006. Some environmental effects on productive performance of Nili-Ravi buffaloes in Azad Kashmir. J. Anim. Pl. Sci., 16(3-4): 66-69.

Javed, K., M.E. Babar, M. Shafiq and A. Ali, 2009. Environmental sources of variation for lactation milk yield in Nili Ravi buffaloes. Pakistan J. Zool. Suppl., 9: 7983.

Johnson, H.D., M.D. Shanklin and L. Hahn, 1989. Productive adaptability indices of Holstein cattle to environmental heat. Agric. Forest Meteorol. Conf., pp. 291297.

Jozwik, A., N. Strzałkowska, E. Bagnicka, W. Grzybek, J. Krzyżewski, E. Poławska, A. Kołataj and J.O. Horbańczuk, 2012. Relationship between milk yield, stage of lactation and some blood plasma metabolic parameters of dairy cows. Czech J. Anim. Sci., 57 (8): 353-360.

Kamiya, M., Y. Iwama, M. Tanaka and S. Shioya, 2005. Effects of high ambient temperature and restricted feed intake on nitrogen utilization for milk production in lactating Holstein cows. Anim. Sci. J., 76: 217-223. 
Khan, A., 1996. Seasonal variation in breeding patterns of buffalo in Punjab. M.Sc. Thesis, Univ. of Agric. Faisalabad, (CVS Lahore).

Koubkova, M., I. Knížková, P. Kunc, H. Härtlová, J. Flusser, O. Doležal, 2002. Influence of high environmental temperatures and evaporative cooling on some physiological, hematological and biochemical parameters in high-yielding dairy cows. Czech J. Anim. Sci., 47 (8): 309-318.

Kuhn, N.J. and J.M. Lowenstein, 1967. Lactogenesis in the Rat, changes in metabolic parameters at parturition. Biochem. J., 105: 995-1002.

Kumar, R. and J.P. Puri, 2009. Influence of environmental variations on blood metabolites in buffaloes. Pakistan J. Zool. Suppl. Ser., 9: 289-291.

LeBlanc, S.J., K.E. Leslie and T.F. Duffield, 2005. Metabolic predictors of displaced abomasum in dairy cattle. J. Dairy Sci., 88: 159-170.

Leung, C.T., B.E. Maleeff and H.M. Farrell, 1989. Subcellular and ultrastructural localization of alkaline phosphatase in lactating rat mammary glands. $J$ Dairy $S c i$ 72: 2495-2509.

Macrae, A.I., D.A. Whitaker, E. Burrough, A. Dowell and J.M. Kelly, 2006. Use of metabolic profiles for the assessment of dietary adequacy in UK dairy herds. Vet. Rec., 159: 655-661.

Marai, I.F.M. and A.A.M. Habeeb, 2010. Buffalo's biological functions as affected by heat stress-a review. Livest. Sci., 127: 89-109.

Marai, I.F.M., A.A.M. Habeeb, A.H. Daader and H.M. Yousef, 1995. Effect of Egyptian subtropical conditions and the heat stress alleviation techniques of water spray and diaphoretics on the growth and physiological functions of Friesian calves. J. Arid Environ., 30: 219-225.

Mc Namara, J.P., J.H. Harrison, R.L. Kincaid and S.S. Waltner, 1995. Lipid metabolism in adipose tissue of cows fed high fat diets during lactation. J. Dairy Sci., 78: 27822796.

Oetzel, G.R., 2004. Monitoring and testing dairy herds for metabolic disease. Vet. Clin. North Am. Food Anim. Pract., 20: 651674.

Oftedal, O.T., 2005. Milk composition, species comparisons. In: W.G. Pond and A.W. Bell (eds), Encyclopedia of Animal Science. Marcel Dekker, Inc., New York, USA. pp. 625-628.

Ozrenk, E. and S.S. Inci, 2008. The effect of seasonal variation on the composition of cow milk in Van Province. Pak. J. Nutr., 7 (1): 161-164.

Rasooli, A., M. Nouri, G.H. Khadjeh and A. Rasekh, 2004. The influence of seasonal variation on thyroid activity and some biochemical parameters of cattle. Iranian J. Vet. Res., 5 (2): 55-62.

Sakowski, T., B. Kuczy, K. Puppel, E. Metera, K. Słoniewskia and J. Barszczewski, 2012. Relationships between physiological indicators in blood, and their yield, as well as chemical composition of milk obtained from organic dairy cows. J. Sci. Food Agric., 92: 2905-2912.

Sevi, A., M. Albenzio, R. Marino, A. Santillo and A. Muscio, 2004. Effects of lambing season and stage of lactation on ewe milk quality. Small Rum. Res., 51: 251-259.

Shafferi, I., J.D. Roussel and K.X. Koonce, 1981. Effects of age, temperature, season and breed on blood characteristics of dairy cattle. J. Dairy Sci., 64 (1): 63-68.

Sobiech, P., S. Milewski and S. Zduńczyk, 2008. Yield and composition of milk and blood biochemical components of ewes nursing a single lamb or twins. Bull. Vet. Inst. Pulawy., 52: 591-596.

SPSS 1999. Statistical Software Package for the Social Sciences. SPSS Int., USA.

Tanaka, M., Y. Kamiya, M. Kamiya and Y. Naka, 2007. Effect of high environmental temperatures on ascorbic acid, sulfhydryl residue and oxidized lipid concentrations in plasma of dairy cows. Anim. Sci. J., 78: 301-306.

Tekelioglu, O., M. Cimen and T. Bayril, 2010. Bovine plasma lipid concentrations in machine milked cows during early lactation period. J. Anim. Plant Sci., 5 (3): 540- 543.

Tyrrell, T F. and J.T. Reid, 1965. Prediction of the energy value of cow's milk. J. Dairy Sci., 48: 1215-1223.

Verma, D.N., S.N. Lal, S.P. Singh, O.M. Parkash and O. Parkash, 2000. Effect of season on biological responses and productivity of buffalo. int. j. anim. sci., 15 (2): 237-244. 
Table 1. Means of ambient temperature $\left({ }^{\circ} \mathrm{C}\right)$, relative humidity $(\%)$ and temperature humidity index (THI) during the whole experimental period from July 2008 to august 2009.

\begin{tabular}{ccccccccc}
\hline \multirow{2}{*}{ Season } & \multicolumn{2}{c}{ Ambient Temperature $\left({ }^{\circ} \mathbf{C}\right)$} & \multicolumn{2}{c}{ Relative Humidity $(\%)$} & \multirow{2}{*}{ THI } \\
\cline { 3 - 7 } Average
\end{tabular}

Table 2. Means \pm SE of milk as affected by season of Egyptian buffaloes during the experiment period (8 weeks)

\begin{tabular}{lccc}
\hline Parameters & Winter & Summer & P \\
\hline DMY (kg) & $4.5 \pm 0.52$ & $2.8 \pm 0.20$ & $* *$ \\
FCM (kg) & $212.8 \pm 23.81$ & $132.7 \pm 10.18$ & $* *$ \\
TMY (kg) & $269.3 \pm 31.23$ & $169.0 \pm 12.46$ & $* *$ \\
Protein (\%) & $3.40 \pm 0.09$ & $3.20 \pm 0.07$ & $*$ \\
Lactose (\%) & $4.77 \pm 0.07$ & $4.74 \pm 0.09$ & $\mathrm{~ns}$ \\
Fat $(\%)$ & $5.02 \pm 0.15$ & $4.90 \pm 0.21$ & $\mathrm{~ns}$ \\
TS $(\%)$ & $13.38 \pm 0.16$ & $13.08 \pm 0.31$ & $\mathrm{~ns}$ \\
SNF $(\%)$ & $8.20 \pm 0.11$ & $7.90 \pm 0.10$ & $*$ \\
\hline
\end{tabular}

DMY $=$ daily milk yield, $\mathrm{FCM}=$ fat corrected milk, TMY $=$ total milk yield, $\mathrm{TS}=$ total solids, $\mathrm{SNF}=$ solids not fat, ${ }^{*}=P \leq 0.05,{ }^{*}=P \leq 0.01, \mathrm{~ns}=$ non-significant.

Table 3. Means $\pm \mathrm{SE}$ of some biochemical parameters as affected by season of Egyptian buffaloes

\begin{tabular}{lccc} 
& & $(\mathbf{n}=\mathbf{1 8})$ & \\
\hline Parameter & Winter & Summer & P \\
\hline ALT (U/I) & $49 \pm 2.2$ & $42 \pm 1.6$ & $*$ \\
AST (U/l) & $121 \pm 5.6$ & $119 \pm 4.4$ & $\mathrm{~ns}$ \\
ALP (U/) & $124 \pm 9.1$ & $113 \pm 8.5$ & $\mathrm{~ns}$ \\
Total Protein (g/dl) & $7.52 \pm 0.23$ & $7.48 \pm 0.23$ & $\mathrm{~ns}$ \\
Albumin (g/dl) & $3.46 \pm 0.13$ & $3.56 \pm 0.11$ & $\mathrm{~ns}$ \\
Globulin (g/dl) & $4.06 \pm 0.13$ & $3.92 \pm 0.16$ & $\mathrm{~ns}$ \\
A/G ratio & $0.85 \pm 0.03$ & $0.93 \pm 0.06$ & $\mathrm{~ns}$ \\
TC (mg/dl) & $86.2 \pm 4.35$ & $67.2 \pm 3.43$ & $* *$ \\
TG (mg/dl) & $42.6 \pm 5.71$ & $45.0 \pm 7.58$ & $\mathrm{~ns}$ \\
\hline
\end{tabular}

$\mathrm{ALT}=$ alanine aminotransferase, $\mathrm{AST}=$ aspartate aminotransferase, $\mathrm{ALP}=$ alkaline phosphatase, $\mathrm{AG}$ ratio $=$ albumin / globulin, $\mathrm{TC}=$ total cholesterol, $\mathrm{TG}=$ triglycerides, ${ }^{*}=P \leq 0.05,{ }^{* *}=P \leq 0.01$, ns $=$ non-significant.

Table 4. Pearson's correlations between biochemical indicators in blood plasma and milk parameters

\begin{tabular}{ccccccccc}
\hline & $\begin{array}{c}\text { DMY } \\
(\mathrm{kg}))\end{array}$ & $\begin{array}{c}\text { FCM } \\
(\mathrm{kg})\end{array}$ & $\begin{array}{c}\text { TMY } \\
(\mathrm{kg})\end{array}$ & $\begin{array}{c}\text { Fat } \\
(\%)\end{array}$ & $\begin{array}{c}\text { Protein } \\
(\%)\end{array}$ & $\begin{array}{c}\text { Lactose } \\
(\%)\end{array}$ & $\begin{array}{c}\text { TS } \\
(\%)\end{array}$ & $\begin{array}{c}\text { SNF } \\
(\%)\end{array}$ \\
\hline ALT (U/I) & $0.361^{*}$ & $0.406^{*}$ & $0.361^{*}$ & $\mathrm{~ns}$ & $\mathrm{~ns}$ & $\mathrm{~ns}$ & $\mathrm{~ns}$ & $\mathrm{~ns}$ \\
AST (U/I) & $\mathrm{ns}$ & $\mathrm{ns}$ & $\mathrm{ns}$ & $\mathrm{ns}$ & $\mathrm{ns}$ & $\mathrm{ns}$ & $\mathrm{ns}$ & $\mathrm{ns}$ \\
ALP (U/I) & $\mathrm{ns}$ & $\mathrm{ns}$ & $\mathrm{ns}$ & $\mathrm{ns}$ & $\mathrm{ns}$ & $0.456^{* *}$ & $0.356^{*}$ & $0.440^{*}$ \\
TG (mg/dl) & $\mathrm{ns}$ & $\mathrm{ns}$ & $\mathrm{ns}$ & $0.330^{*}$ & $\mathrm{~ns}$ & $\mathrm{~ns}$ & $\mathrm{~ns}$ & $\mathrm{~ns}$ \\
TC (mg/dl) & $\mathrm{ns}$ & $0.375^{*}$ & $\mathrm{~ns}$ & $\mathrm{~ns}$ & $\mathrm{~ns}$ & $\mathrm{~ns}$ & $\mathrm{~ns}$ & $\mathrm{~ns}$ \\
Albumin (g/dl) & $\mathrm{ns}$ & $\mathrm{ns}$ & $\mathrm{ns}$ & $\mathrm{ns}$ & $\mathrm{ns}$ & $\mathrm{ns}$ & $\mathrm{ns}$ & $\mathrm{ns}$ \\
Globulin (g/dl) & $\mathrm{ns}$ & $\mathrm{ns}$ & $\mathrm{ns}$ & $\mathrm{ns}$ & $\mathrm{ns}$ & $\mathrm{ns}$ & $\mathrm{ns}$ & $\mathrm{ns}$ \\
A/G ratio & $-0.30^{*}$ & $\mathrm{~ns}$ & $\mathrm{~ns}$ & $\mathrm{~ns}$ & $\mathrm{~ns}$ & $\mathrm{~ns}$ & $\mathrm{~ns}$ & $\mathrm{~ns}$ \\
\hline
\end{tabular}

DMY = daily milk yield, $\mathrm{FCM}=$ fat corrected milk, $\mathrm{TMY}=$ total milk yield, $\mathrm{TS}=$ total solids, $\mathrm{SNF}=$ solids not fat, $\mathrm{AST}=$ aspartate aminotransferase, $\mathrm{ALT}=$ alanine aminotransferase, $\mathrm{ALP}=$ alkaline phosphatase, $\mathrm{TG}=$ Triglycerides, Glob $=$ globulin, $\mathrm{AG}$ ratio $=$ albumin $/$ globulin, $\mathrm{ns}=$ non-significant. 
أداء إنتاج اللبن وبعض المكونات البيوكيميائية في الام للجاموس المصري وتأثرها بالتغير الموسمي

محمد حمدي فاروق

\section{قسم الإنتاج الحيوانس، كلية الززراعة، جامعة الأزهر، مدينة نصر، القاهرة}

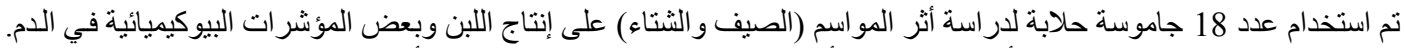

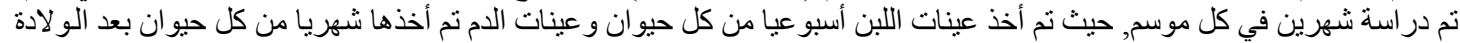

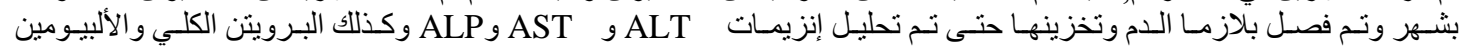

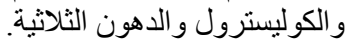

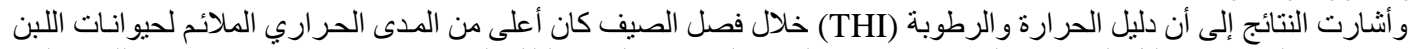

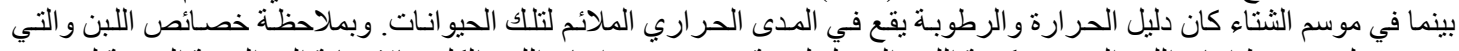

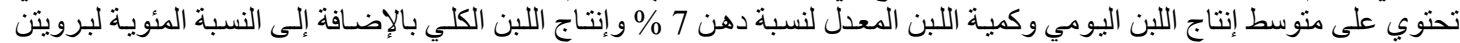

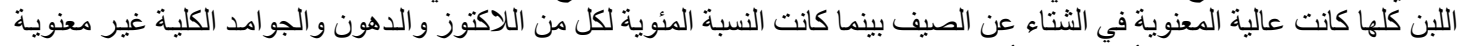



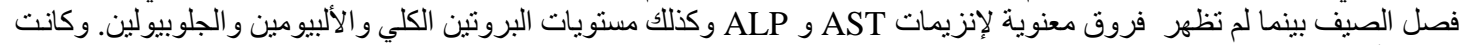

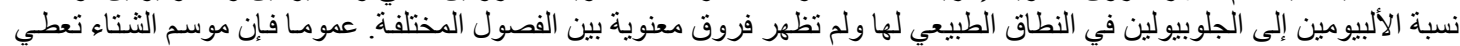

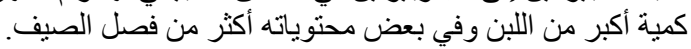

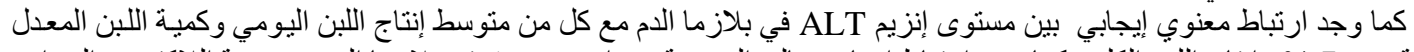

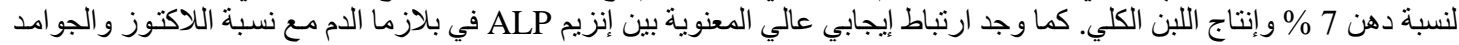

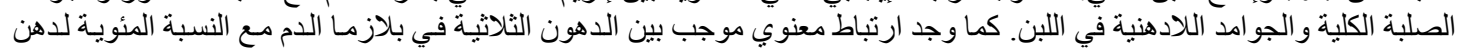

